\title{
The Interplay between Long Noncoding RNAs and Proteins of the Epigenetic Machinery in Ovarian Cancer
}

\author{
Naiade Calanca ${ }^{1}\left(\mathbb{0}\right.$, Cecilie Abildgaard ${ }^{2,3}{ }^{(}$, Cláudia Aparecida Rainho $^{1}(\mathbb{D}$ and \\ Silvia Regina Rogatto ${ }^{3, *}$ \\ 1 Department of Chemical and Biological Sciences, Institute of Biosciences, São Paulo State \\ University (UNESP), Botucatu 18618-689, Brazil; naiade.calanca@unesp.br (N.C.); \\ claudia.rainho@unesp.br (C.A.R.) \\ 2 Department of Oncology, University Hospital of Southern Denmark-Vejle, Institute of Regional Health \\ Research, University of Southern Denmark, 5000 Odense, Denmark; Cecilie.Abildgaard@rsyd.dk \\ 3 Department of Clinical Genetics, University Hospital of Southern Denmark-Vejle, Institute of Regional \\ Health Research, University of Southern Denmark, 5000 Odense, Denmark \\ * Correspondence: silvia.regina.rogatto@rsyd.dk; Tel.: +45-7940-6669
}

Received: 20 August 2020; Accepted: 16 September 2020; Published: 21 September 2020

Simple Summary: Epithelial ovarian cancer is an aggressive disease associated with relapse, resistance to chemotherapy, and high mortality rates. Recent discoveries have pointed out that long noncoding RNAs (lncRNAs) are potential biomarkers or therapeutic targets in several tumor types. However, fundamental knowledge about their functions and regulation is still lacking. Here, we present the current understanding of the interplay between lncRNAs and the epigenetic machinery influencing ovarian carcinogenesis. We also provide an overview of bioinformatics tools and databases that can be exploited for lncRNAs investigations. Altogether, this information can support the development of clinical initiatives to monitor disease progression or discover new strategies for the therapeutic management of ovarian cancer.

\begin{abstract}
Comprehensive large-scale sequencing and bioinformatics analyses have uncovered a myriad of cancer-associated long noncoding RNAs (lncRNAs). Aberrant expression of lncRNAs is associated with epigenetic reprogramming during tumor development and progression, mainly due to their ability to interact with DNA, RNA, or proteins to regulate gene expression. LncRNAs participate in the control of gene expression patterns during development and cell differentiation and can be cell and cancer type specific. In this review, we described the potential of IncRNAs for clinical applications in ovarian cancer (OC). OC is a complex and heterogeneous disease characterized by relapse, chemoresistance, and high mortality rates. Despite advances in diagnosis and treatment, no significant improvements in long-term survival were observed in OC patients. A set of lncRNAs was associated with survival and response to therapy in this malignancy. We manually curated databases and used bioinformatics tools to identify lncRNAs implicated in the epigenetic regulation, along with examples of direct interactions between the lncRNAs and proteins of the epigenetic machinery in OC. The resources and mechanisms presented herein can improve the understanding of OC biology and provide the basis for further investigations regarding the selection of novel biomarkers and therapeutic targets.
\end{abstract}

Keywords: lncRNAs; epigenetic regulators; transcriptional regulation; ovarian cancer; lncRNA databases 


\section{Introduction}

Despite the advances in diagnosis and treatment in the last decades, ovarian cancer $(\mathrm{OC})$ is still considered a clinical challenge due to the absence of improvements in long-term survival [1,2]. Based on the Global Cancer Observatory (GLOBOCAN) estimates of cancer incidence and mortality, OC is a health problem worldwide, and the second cause of death among gynecological malignancies, after cervical cancer [3]. In 2018, it accounted for 295,414 new cases and 184,799 deaths globally [4]. This disease is considered complex, being characterized by heterogeneity at molecular, histological, and clinical levels [5]. OC is classified into different subtypes according to cell origin (epithelial, sex-cord stromal, germ cell, and mixed-cell type) and histological features [6]. Epithelial ovarian cancer (EOC) is the most common type of malignancy that affects ovaries (approximately $90 \%$ ). Furthermore, multiple histological subtypes characterize the EOC, including serous, endometrioid, clear cell, mucinous, and malignant Brenner. Of these, high-grade serous ovarian carcinoma (HGSOC) is the most commonly diagnosed type and accounts for $70-80 \%$ of deaths from the whole spectrum of OC subtypes [7]. This cancer type is commonly associated with relapse and chemoresistance [8]. $\mathrm{OC}$ is frequently diagnosed at advanced stages, partly because these tumors often exhibit nonspecific symptoms at the first stages of the disease, and due to the absence of effective screening strategies for early detection $[9,10]$. The aggressive nature of the disease, commonly causing transcoelomic dissemination, adds to the poor prognosis of less than 30\% 5-year survival for stage III and IV tumors [11,12]. Platinum-based chemotherapy is the primary treatment option, often combined with a taxane-based drug, namely paclitaxel. Several targeted therapies such as bevacizumab, an inhibitor of vascular endothelial growth factor (VEGF) or PARP (Poly-ADP-ribose-polymerase) inhibitors of proteins can be administered first-line or as a second-line treatment for the recurrent disease [13,14]. Although most patients initially respond well to chemotherapy, it is estimated that $80 \%$ of OC patients at advanced-stage will experience recurrence of their primary cancer [8].

The improvement in high-throughput technologies, such as tiling arrays and Next Generation Sequencing (NGS), as well as bioinformatics analyses have extended the boundaries of our knowledge about the noncoding sequences in the human genome. Once considered junk DNA, these sequences underwent a paradigm shift after the discovery that the human genome is pervasively transcribed. Although approximately $80 \%$ of the human genome is transcribed into RNAs, only a small fraction of them is associated with protein-coding exons $[15,16]$. This suggests that most DNA sequences can be transcribed but not to encode proteins, generating noncoding RNAs (ncRNAs). This information has altered our perception of this RNA class and led to increased attention to their functional roles as regulators of physiological programs during development and human diseases, including cancer [17]. These ncRNAs are involved in regulatory and structural functions in cells and are usually are classified into two main categories according to the molecule size: long and short noncoding RNAs. Long noncoding RNAs (lncRNAs) are a group of transcripts with more than 200 nucleotides in length and were initially defined by the apparent absence of protein-coding potential [18].

Through direct interactions with DNA, RNA, or proteins, IncRNAs exert regulatory roles over their target genes at transcriptional, post-transcriptional, and epigenetic levels in a broad range of biological processes, including coordination of allelic expression, cell cycle control, stem cell pluripotency maintenance, differentiation, and apoptosis $[19,20]$. Considering the relevance of these processes in health and disease and the great diversity of lncRNAs encoded by the human genome, it is not surprising that these transcripts have been linked to almost all hallmarks of cancer [21]. Coined by Hanahan and Weinberg, these hallmarks correspond to the traits acquired by cells that allow malignant transformation [22]. The regulation of gene expression mediated by lncRNAs may involve the epigenetic mechanisms by direct interactions with proteins of the epigenetic machinery, including histone modifications and chromatin remodeling [23]. The interplay between differentially expressed lncRNAs, such as MALAT1 (metastasis-associated lung adenocarcinoma transcript 1) and CDKN2B-AS1 (cyclin-dependent kinase inhibitor 2B antisense RNA 1), and histone-modifying or chromatin-remodeling complexes has been implicated in transcriptional regulation, enabling 
progression of different cancer types [24]. A set of the OC-related lncRNAs acts as oncogenes or tumor suppressors, contributing to cellular transformation [25-27].

The aberrant expression levels of these lncRNAs can be detected in tumor tissues and body fluids. Some lncRNAs were found to be widely dysregulated, such as HOTAIR (HOX transcript antisense RNA), whereas others are specifically altered in one or a few tumor types $[28,29]$. In EOC, it was demonstrated that hundreds of IncRNAs are differentially expressed compared to benign and normal control tissues [30]. Furthermore, some of them, either individually or as part of molecular signatures, exhibit a significant association with clinical outcomes, such as disease-free (DFS) and overall survival (OS) [31,32]. For instance, increased levels of the IncRNA HOTAIR, previously reported in EOC tissues, showed an association with a surrogate DNA methylation profile that predicts poor survival in patients treated with carboplatin [33]. Recently published reviews provide additional examples of differentially expressed lncRNAs associated with OC prognosis [31,34,35]. In light of the growing body of evidence, it can be understood why lncRNAs could serve not only as prognostic and predictive markers but also as highly specific therapeutic targets. However, to date, few lncRNAs have been recognized as key players in the resistance to therapy in OC.

Overall, most of the well-characterized lncRNAs are associated with the gene expression regulation, commonly at transcriptional rather than at the post-transcriptional level. Importantly, IncRNAs may contribute to tumor biology by directly interacting with proteins of the epigenetic machinery or chromatin-remodeling complexes. The interplay between lncRNAs and these proteins results in epigenetic silencing or activation of target loci in a cis or trans-regulatory manner by altering chromatin structure, histone marks, or DNA methylation patterns of proximal regulatory elements. In this review, we revisit the opportunities to explore lncRNAs associated with the disruption of epigenetic reprogramming in OC. We also provided a guide for databases and tools that could help select disease-related lncRNAs for future functional studies and potential clinical applications.

\section{LncRNA Genes and Their Expression Patterns}

Although lncRNAs were previously recognized as noncoding genes, recent evidence has suggested that many of them contain small open reading frames that are strongly associated with ribosomes, which results in the translation of small peptides [36]. Several of these small peptides, often comprising fewer than 100 amino acids, are biologically functional and even implicated in cancer-suppressive or cancer-promoting activities [37]. Alternatively, some studies have linked mRNAs to coding-independent regulatory functions, blurring the differences between coding and noncoding transcripts, and highlighting the emergence of a new class of bifunctional RNAs [38].

LncRNAs are widely expressed in human tissues and, while less abundant, they are more tissue-specific than protein-coding genes $[39,40]$. Based on the genomic positions relative to protein-coding genes, IncRNAs can be classified into intergenic or intragenic, and sense, antisense, or bidirectional lncRNAs [41]. They share the same transcriptional machinery as protein-coding genes and usually undergo similar co-transcriptional and post-transcriptional processing events: 5 '-capping, splicing, and 3'-polyadenylation [42]. Thus, standard RNA-seq protocols allow the identification of most lncRNA sequences [43]. In the evolutionary context, lncRNA exons evolve at a higher rate than protein-coding exons and lncRNA homologs exhibit limited sequence similarity in comparison with protein-coding genes [43]. As for genome diversity, IncRNAs surpass their protein-coding counterparts: lncRNA genes amount to nearly 60,000, against approximately 20,000 protein-coding genes [15,39].

From this myriad of lncRNAs, only a small part was deeply studied, and some patterns of action were proposed to depict their functions and help to predict the activities of other transcripts yet to be characterized. Molecularly, lncRNAs act by four mechanisms: as signals, reflecting biological contexts that are crucial for gene regulation in space and time; as scaffolds, binding to several proteins simultaneously and allowing the assembly of multi-subunit complexes; as guides, recruiting regulatory complexes to target loci in cis or trans via RNA-protein and RNA-DNA interactions; as decoys, regulating the availability of other biomolecules through sequestration [44]. A single 
IncRNA frequently presents more than one mechanism of action. Most lncRNAs are exclusively localized in the nucleus, although some lncRNAs can occupy the chromatin and subnuclear domains or the cytoplasm. These localization patterns are possibly related to a particular lncRNA function [45]. Nuclear transcripts can perform their regulatory roles by interacting with epigenetic regulators and, consequently, affect DNA methylation, chromatin architecture, or histone marks deposition in cis and trans [46].

Besides the linear isoforms, lncRNA genes can generate transcripts with circular structures, called circRNAs [47]. The CDKN2A/B (cyclin-dependent kinase inhibitor 2A/B) locus, for instance, is known for its linear antisense ncRNA $C D K N 2 B-A S 1$ that interacts with the histone-modifying complexes Polycomb Repressive Complex 1 and 2 (PRC1 and PRC2, respectively) and mediates transcriptional regulation. This mechanism was implicated in epigenetic silencing of tumor suppressor genes in the carcinogenesis process [48]. Apart from its linear isoform, the CDKN2B-AS1 gene can produce circular transcripts by alternative splicing. The expression of these molecules was associated with atherosclerotic vascular disease risk [49]. Importantly, numerous circRNAs were found to be overexpressed in the serum of OC patients, whereas others, such as circ_0051240, circ-HIPK3 (homeodomain interacting protein kinase 3), and circRNA-UBAP2 (ubiquitin associated protein 2), were implicated in the control of OC cells malignant behavior [50,51]. CircRNAs are more stable in cells than their linear counterparts due to their covalent closed-loop structure. The lack of 5 'end and poly(A)-tail come as a result of the circRNA biogenesis process, usually by lariat-driven circularization or back splicing, and avoid degradation by ribonucleases [52]. RNA-seq datasets obtained with poly(A)-independent methods are required for circRNA detection. However, the library preparation procedures still lack standardization, since there are several approaches to enrich the circRNA content (e.g., poly(A) depletion, rRNA depletion, and RNase R treatment), which lead to variability in results [53].

Pseudogenes are generally derived from their parental genes that underwent insertions, deletions, or nucleotide substitutions and lost their ability to encode for functional proteins. Therefore, pseudogenic transcripts can exert regulatory roles modulating the expression and/or the function of their cognate genes or unrelated coding genes [54]. Additionally, a subgroup of pseudogene loci can express lncRNAs, besides producing endogenous small interfering RNAs (siRNAs) [54]. The PTENP1 (phosphatase and tensin homolog pseudogene 1) pseudogene, for example, encodes sense and antisense IncRNA transcripts that act to modulate the expression of its parental gene, the tumor suppressor PTEN (phosphatase and tensin homolog). Taking into account the experimental evidence of its involvement in tumor development and progression, either regulating PTEN or other genes, PTENP1 can be considered a tumor suppressor [55].

The dysregulated expression of lncRNAs in cancer and their prominent spatial and temporal specificity compared with protein-coding genes reinforces their appeal as potential biomarkers and therapeutic targets [56]. Similar to lncRNAs, circRNAs present tissue/developmental stage-specificity and aberrant expression in cancer [57]. The increased stability, accompanied by their abundance in exosomes and body fluids, make circRNAs even more attractive for clinical applications $[57,58]$. As for pseudogenes, their expression is generally restricted to tumor tissues or increased in tumors compared to normal tissues [59]. In the fifth section, we present some invaluable resources to evaluate the abnormal expression levels and other features displayed by these noncoding transcripts in normal and pathological conditions.

\section{LncRNAs and Their Association with Ovarian Cancer}

In EOC, certain IncRNAs were found to be differentially expressed compared with benign and normal tissues. For instance, Wang et al. (2016) reported the up- or downregulation of 663 lncRNAs. The expression of the antisense lncRNA RP11-597D13.9 was positively correlated with its nearby coding gene, FAM198B (family with sequence similarity 198 member B, also known as Golgi associated kinase 1B or GASK1B), which potentially participates in EOC progression [30]. Based on a systematic analysis of IncRNA and mRNA expression profiles from The Cancer Genome Atlas (TCGA), a platinum 
resistance-specific lncRNA-mRNA network was identified in HGSOC [60]. A total of 35 lncRNAs and 270 mRNAs showed 124 significant lncRNA-mRNA co-expression relationships in this network. The study revealed that the lncRNAs involved in platinum resistance primarily regulate metabolic pathways and indicates the prognostic and therapeutic potential of lncRNAs in HGSOC [60]. Another study, including TCGA-HGSOC datasets, identified a 10-lncRNA prognostic signature that enabled to group the patients into low-, mid-, and high-risk groups, indicating significantly shorter OS and DFS for women in the last group [32].

LncRNA expression profiles of OC patients have been analyzed from GEO (Gene Expression Omnibus) datasets. These studies have used different bioinformatics approaches and included distinct datasets, with a little overlap between them. Song et al. (2018) reported a signature with seven lncRNAs (RP11-126K1.6, ZBED3-AS1, RP11-439E19.10, RP11-348N5.7, RNF144A-AS1, GAS5, and F11-AS1) [61], whereas Liu et al. (2017) identified a signature with eight lncRNAs (ZFAS1, RP5-1061H20.5, RP11-489018.1, RP11-16E12.1, LINC01514, TUG1, RP11-136114.5, and CTD-2555A7.3) [62], both able to predict the response of HGSOC patients to platinum-based chemotherapy [61,62]. A signature composed of seven different lncRNAs (XR_948297, XR_947831, XR_938728,XR_938392, NR_103801, $N R \_073113$, and NR_036503) was significantly correlated with a poor response to treatment with paclitaxel in EOC patients [63]. Another signature comprising six lncRNAs (RUNX1-IT1, MALAT1, H19, HOTAIRM1, LOC100190986, and AL132709.8) was associated with recurrence in OC [64]. Overall, these studies revealed several lncRNAs linked to EOC via cancer-related functions and pathways, according to GO (Gene Ontology) and KEGG (Kyoto Encyclopedia of Genes and Genomes) enrichment analyses.

To date, a few lncRNAs commonly associated with cancer were also involved in OC outcomes. A set of abnormally expressed lncRNAs, such as H19 (H19 imprinted maternally expressed transcript), HOTAIR, and CDKN2B-AS1 was associated with patient survival [35]. The overexpression of the lncRNA HOTAIR in EOC tissues was positively correlated with the FIGO (International Federation of Gynecology and Obstetrics) stage, histological grade, lymph node metastasis, and inversely correlated with OS and DFS [65]. The knockdown of HOTAIR suppressed cell proliferation, reduced invasion, and restored cisplatin-sensitivity, specifically by enhancing chemotherapy-induced cytotoxicity and apoptosis in cisplatin-resistant OC cell lines [66]. Upregulated lncRNAs CCAT2 (colon cancer-associated transcript 2), LSINCT5 (long stress-induced noncoding transcript 5), CERNA2 (competing endogenous lncRNA 2 for microRNA let-7b), PVT1 (Pvt1 oncogene), UCA1 (urothelial cancer-associated 1), and NEAT1 (nuclear paraspeckle assembly transcript 1) have also been implicated in cancer-promoting mechanisms in OC [67]. An additional example is GAS5 (growth arrest-specific 5), which was found to be downregulated in OC and associated with poor prognosis [68]. Experimental assays inducing GAS5 overexpression inhibited cell proliferation, migration, and invasion, besides promoting apoptosis [68].

The oncogenic and tumor suppressor actions of HOTAIR and GAS5, respectively, have been also described for other lncRNAs. LEMD1-AS1 (LEMD1 antisense RNA 1), for instance, inhibits OC progression by regulating an axis including miR-183-5p and TP53 (tumor protein p53) and leading to decreased cell proliferation, migration, and invasion [69]. MAGI2-AS3 (MAGI2 antisense RNA 3) downregulates MYC (MYC proto-oncogene, bHLH transcription factor) transcriptional activity via targeting the miR-525-5p/ MXD1 (MAX dimerization protein 1) axis [70]. OC cell growth and motility are repressed as a consequence of MAGI2-AS3 induced overexpression. Conversely, the silencing of DLX6-AS1 (distal-less homeobox 6 antisense RNA 1) impaired proliferation, migration, and invasion abilities of OC cells, besides inducing their apoptosis and repressing tumor growth in vivo [25]. Increased levels of DLX6-AS1 were detected in OC cells and tissues [25]. The authors demonstrated that DLX6-AS1 acts by sponging the miR-195-5p and upregulating its miRNA-target FHL2 (four and a half LIM domains 2). Likewise, TMPO-AS1 (thymopoietin antisense RNA 1) knockdown significantly suppressed OC cell proliferation, migration, invasion, and angiogenesis, also inhibiting tumorigenesis and angiogenesis in vivo [26]. TMPO-AS1 was found to be upregulated in OC cell lines and clinical samples and exerts its oncogenic role by binding to E2F6 (E2F transcription factor 6) and modulating 
its occupancy on the promoter region of LCN2 (lipocalin 2), whose expression is activated. These examples highlight the potential of targeting lncRNAs for OC treatment.

In addition to the molecular signatures presented earlier, single lncRNAs have also been shown to affect response to therapy in $\mathrm{OC}$, although the understanding of the underlying mechanisms is still in its infancy [31]. The well-known oncogenic lncRNAs MALAT1, HOTAIR, and PANDAR (promoter of CDKN1A antisense DNA damage-activated RNA) were associated with cisplatin resistance [71-73]. The silencing of MALAT1 was demonstrated to enhance sensitivity to cisplatin due to the reduced downstream NOTCH1 (notch receptor 1) signaling, which led to the repression of the multidrug resistance gene $A B C C 1$ (ATP binding cassette subfamily $C$ member 1) [72]. HOTAIR acts as a sponge for the miR-138-5p. The knockdown of HOTAIR was recently demonstrated to reverse cisplatin resistance due to the increased availability of the miR-138-5p repressing EZH2 (enhancer of zeste 2 polycomb repressive complex 2 subunit) and SIRT1 (sirtuin 1) [74]. Both MALAT1 and HOTAIR have been suggested as potential therapeutic targets to restore platinum sensitivity. The overexpression of PVT1 and HOTAIR were implicated in cisplatin resistance in cell line models by regulating apoptotic factors or activating the NF- $\mathrm{KB}$ (nuclear factor kappa B) pathway, respectively $[75,76]$. Intriguingly, increased levels of PVT1 after carboplatin-docetaxel treatment induced TP53 and TIMP1 (tissue inhibitor of metalloproteases-peptidase inhibitor 1) proteins expression concomitantly to decreased cell proliferation [77]. Acting by an unknown mechanism, the lncRNA UCA1 promotes the expression of kinase SRPK1 (SRSF protein kinase 1), which was associated with increased proliferation and reduced apoptosis of OC cells, favoring the development of cisplatin resistance [78]. Interestingly, Adriaens et al. (2016) suggested that targeting the lncRNA NEAT1 can sensitize OC to platinum-based chemotherapy since its isoform 2 is involved in genomic integrity preservation by modulating ATR-CHK1 (ATM and Rad3-related-checkpoint 1) signaling and potentially affects double-stranded break (DSB) repair [79].

\section{LncRNAs Involved in Epigenetic Mechanisms in Ovarian Cancer}

The role of epigenetic machinery elements generally fits into one of three patterns of activity: (i) the writers can transfer chemical groups to nucleotide bases in DNA or amino acid residues in histone tails, (ii) the erasers are capable of removing these marks, and (iii) the readers are specialized in recognizing the DNA and histone epigenetic modifications. The writers include DNA methyltransferases (DNMTs), histone methyltransferases (HMTs), and histone acetyltransferases (HATs), while DNA demethylases, histone demethylases (HDMs), and histone deacetylases (HDACs) are their eraser counterparts. These molecules usually act in gene expression regulation by associating with lncRNAs and transcription factors [80,81]. In this section, we provide examples of lncRNAs whose interaction with proteins of the epigenetic machinery is supported by strong experimental evidence and potentially influence OC outcomes (Figure 1). These examples were obtained by searching either the lncRNA databases listed or from the published literature, i.e., referring to recent studies not included in databases (Table 1).

The knowledge of the interplay between lncRNAs, epigenetic machinery, and transcriptional regulation could significantly expand our understanding of how lncRNA dysregulation contributes to the epigenome and transcriptome alterations and, consequently, to tumor initiation and progression. LncRNAs participate in the epigenetic regulation by several mechanisms, including (i) interaction with DNMTs, guiding these proteins to a specific locus, leading to the promoter methylation and repression of tumor suppressor genes; (ii) by changing the nucleosome positioning and modifying chromatin accessibility to the transcriptional machinery; (iii) by recruiting histone-modifying enzymes in cis or trans. Another possible mechanism considers that lncRNAs can recruit demethylases and/or acetylases to the promoter region of oncogenes, and consequently activate them $[82,83]$.

Hu et al. (2014) demonstrated the interaction between the lncRNA FALEC (focally amplified long noncoding RNA in epithelial cancer), also known as FAL1, and BMI1 (BMI1 proto-oncogene), a core component of PRC1. The authors reported the association of FAL1 expression levels to the stabilization of BMI1 protein in human OC cell lines [84]. 
Table 1. Representative lncRNAs associated with disruption of epigenetic mechanisms in ovarian cancer.

\begin{tabular}{|c|c|c|c|c|}
\hline LncRNA & $\begin{array}{l}\text { Regulatory } \\
\text { Mechanism }\end{array}$ & Target & Source & Refs. \\
\hline FAL1 (FALEC) & $\begin{array}{l}\text { Stabilization of } \\
\text { BMI1 protein and } \\
\text { PRC1-mediated } \\
\text { deposition of } \\
\text { repressive histone } \\
\text { marks }\end{array}$ & CDKN1A & $\begin{array}{c}\text { LncTarD and } \\
\text { EVLncRNAs } \\
\text { databases }\end{array}$ & {$[84,85]$} \\
\hline PVT1 & EZH2 recruitment & miR-214 & LncTarD database & [86] \\
\hline TARID & $\begin{array}{l}\text { Recruitment of } \\
\text { GADD45A and } \\
\text { TET-dependent } \\
\text { DNA } \\
\text { demethylation }\end{array}$ & TCF21 & LncTarD database & {$[87,88]$} \\
\hline LINC01210 & $\begin{array}{l}\text { EZH2 recruitment } \\
\text { and } \\
\text { PRC2-mediated } \\
\text { deposition of } \\
\text { repressive histone } \\
\text { marks }\end{array}$ & KLF4 & Literature mining & [89] \\
\hline TP73-AS1 & $\begin{array}{l}\text { EZH2 recruitment } \\
\text { and } \\
\text { PRC2-mediated } \\
\text { deposition of } \\
\text { repressive histone } \\
\text { marks }\end{array}$ & CDKN1A & Literature mining & [90] \\
\hline UNC5B-AS1 & $\begin{array}{l}\text { EZH2 recruitment } \\
\text { and } \\
\text { PRC2-mediated } \\
\text { deposition of } \\
\text { repressive histone } \\
\text { marks }\end{array}$ & NDRG2 & Literature mining & [91] \\
\hline$A B H D 11-A S 1$ & $\begin{array}{l}\text { EZH2 recruitment } \\
\text { and } \\
\text { PRC2-mediated } \\
\text { deposition of } \\
\text { repressive histone } \\
\text { marks }\end{array}$ & TIMP2 & Literature mining & [92] \\
\hline
\end{tabular}

ABHD11-AS1: ABHD11 antisense RNA 1 (tail to tail); BMI1: BMI1 proto-oncogene, polycomb ring finger; CDKN1A: cyclin-dependent kinase inhibitor 1A; EZH2: enhancer of zeste 2 polycomb repressive complex 2 subunit; FALEC: focally amplified long noncoding RNA in epithelial cancer; GADD45A: growth arrest and DNA damage-inducible alpha; KLF4: Kruppel like factor 4; LINC01210: long intergenic nonprotein coding RNA 1210; NDRG2: NDRG family member 2; PRC1: Polycomb Repressive Complex 1; PRC2: Polycomb Repressive Complex 2; PVT1: Pvt1 oncogene; TARID: TCF21 antisense RNA inducing promoter demethylation; TCF21: transcription factor 21; TET: ten-eleven translocation family; TIMP2: TIMP metallopeptidase inhibitor 2; TP73-AS1: TP73 antisense RNA 1; UNC5B-AS1: UNC5B antisense RNA 1.

The PRC1 histone-modifying complex is known for binding the promoter regions of its target genes and mediating the deposition of one ubiquitin group to histone H2A at lysine 119 (H2AK119ub) [93]. However, the significance of this mark to the transcriptional repression of target genes is not yet fully understood. A novel mechanism was recently described for BMI1, which works in a PRC1-independent and non-epigenetic manner to regulate androgen receptor protein in castration-resistant prostate cancer [94]. Nevertheless, in Hu et al. (2014) study, the depletion of FAL1 was correlated with the upregulation of CDKN1A (cyclin-dependent kinase inhibitor 1A). Experimental evidence suggests that the underlying mechanism involves, at least in part, the modulation of BMI1 occupancy and 
ubiquitination of H2AK119 on the promoter region of CDKN1A. The p21 protein encoded by CDKN1A promotes cell-cycle arrest and senescence. In vitro and in vivo studies demonstrated that both these processes were positively regulated by FAL1 knockdown. Thus, FAL1 has an oncogenic function in OC partly exerted by the epigenetic regulation of p21 expression levels, hinting at potential implications for cancer therapy [84].

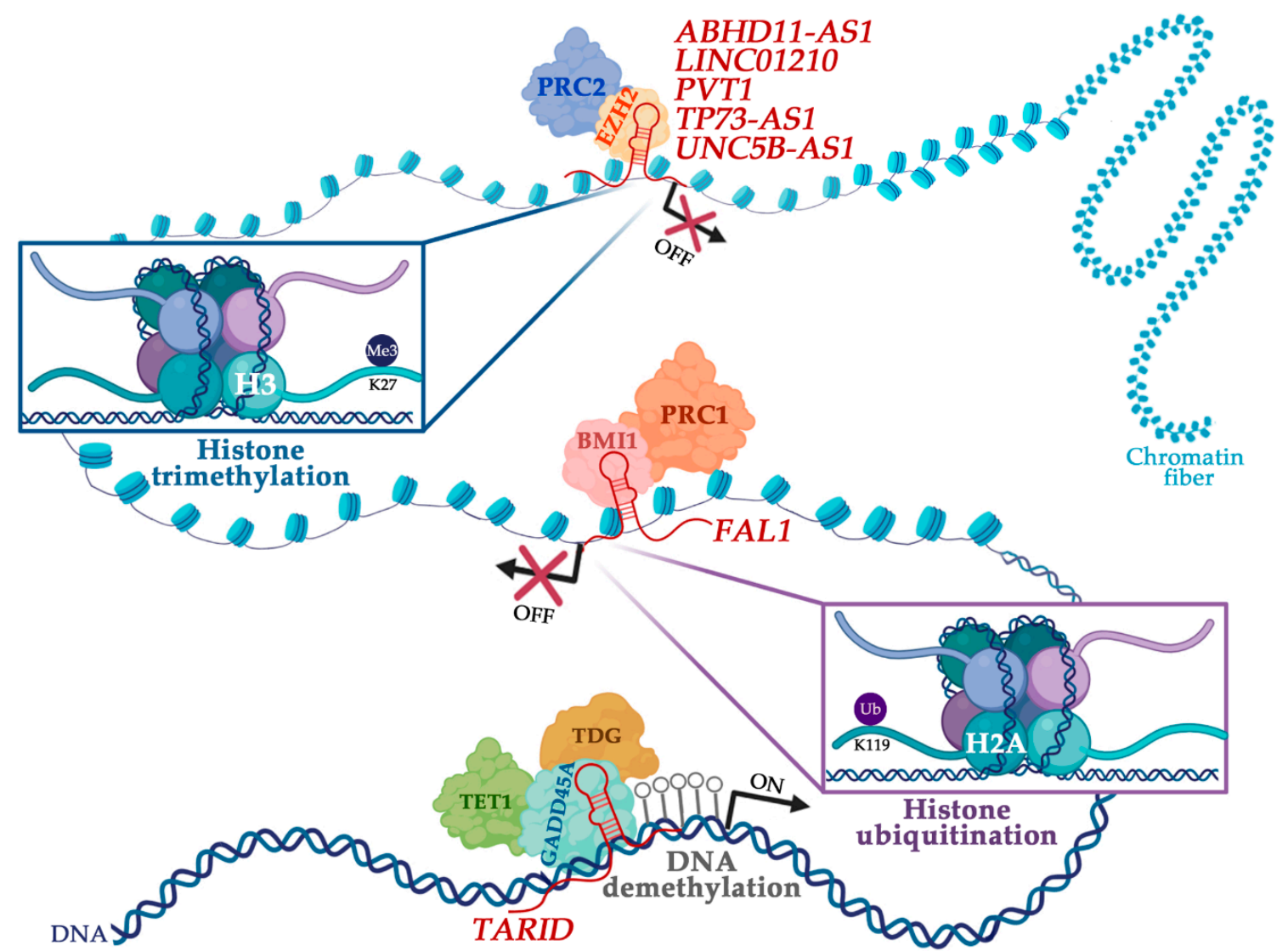

Figure 1. Long noncoding RNAs (lncRNAs) as epigenetic regulators in ovarian cancer. The representative lncRNAs implicated in each regulatory mechanism are shown in dark red. In the top and center, the interplay between lncRNAs and repressive histone-modifying complexes (Polycomb Repressive Complexes 2 and 1, respectively) are illustrated. The functional relationship between the lncRNA TARID (TCF21 antisense RNA inducing promoter demethylation) and the DNA demethylation is presented at the bottom of the figure. (Created with biorender.com).

The lncRNA PVT1 recruits the protein EZH2 to the promoter of miR-214 [86]. EZH2 is one of two alternative catalytic subunits of PRC2 and is required, along with two other core components (SUZ12 polycomb repressive complex 2 subunit and embryonic ectoderm development), to produce the repressive histone modifications that characterize PRC2 activity: mono-, di-, and trimethylation of histone $\mathrm{H} 3$ at lysine 27. Under physiological conditions, the complex is recruited to unmethylated $\mathrm{CpG}$ islands and ensures the maintenance of previously established transcriptional silencing states, contributing to preserving cell identity [95]. In EOC, the upregulation of EZH2 has been reported by several studies and promotes proliferation, invasion, metastasis, and angiogenesis, besides its association with cisplatin resistance in OC cells [96].

In OC, both overexpression and downregulation of miR-214 have been described [97]. In the first case, this miRNA was implicated in reducing the cisplatin-induced apoptosis by targeting PTEN, whereas downregulation was linked to cancer cell stem-like properties and conversion of normal fibroblasts into cancer-associated fibroblasts [97]. Chen and colleagues identified increased PVT1 
and decreased miR-214 expression levels in EOC tissue samples and OC cell lines in comparison to normal tissue samples and human primary ovarian cells, respectively. In vitro results demonstrated the interaction between EZH2 and PVT1 and the association of the lncRNA with proliferation, migration, and invasion [86].

Additional examples of lncRNAs capable of recruiting EZH2 to transcriptionally repress their target genes are LINC01210 (long intergenic nonprotein coding RNA 1210), TP73-AS1 (TP73 antisense RNA 1), UNC5B-AS1 (UNC5B antisense RNA 1), and ABHD11-AS1 (ABHD11 antisense RNA 1 (tail to tail)). Increased expression levels of LINC01210 were reported in OC tissues, notably in metastatic or advanced stages of the disease, which were correlated with poor prognosis [89]. This lncRNA epigenetically downregulates the transcription factor KLF4 (Kruppel-like factor 4), favoring cell proliferation, invasion, and migration [89]. In OC, induced KLF4 overexpression promoted apoptosis and improved the efficacy of chemotherapy drugs (cisplatin and paclitaxel) [98]. Similar to the IncRNA FAL1, TP73-AS1 mediates epigenetic repression of the tumor suppressor CDKN1A, although through with EZH2 instead of BMI1. TP73-AS1 is upregulated in EOC tissues and cell lines, correlating with poor prognosis, and facilitating tumor progression by targeting CDKN1A [90].

The lncRNA UNC5B-AS1 and its target gene NDRG2 (NDRG family member 2) have been poorly explored in OC. NDRG2 has been associated with tumor suppression in several cancer types and was found to be downregulated in OC tissues and cell lines [91]. In this context, UNC5B-AS1 recruits EZH2 to inhibit NDRG2 transcription, promotes cell proliferation, and impairs apoptosis [91]. To confirm bioinformatic predictions, $A B H D 11-A S 1$ was experimentally proven to interact with EZH2 leading to the epigenetic repression of TIMP2 (TIMP metallopeptidase inhibitor 2) and further promoting invasion and metastasis [92]. This evidence sheds light on the function of ABHD11-AS1 in OC, albeit the inverse correlation between EZH2 and TIMP2 expression levels had already been detected in EOC tissues [99]. TIMP2 is a member of the TIMP gene family, which encodes proteins that inhibit the activity of matrix metalloproteinases. The metalloproteinases degrade the extracellular matrix and facilitate metastasis initiation. Unsurprisingly, TIMP2 aberrant expression promotes cell growth and invasion in several malignancies [92].

The antisense lncRNA TARID (TCF21 antisense RNA inducing promoter demethylation) mediates demethylation of the protein-coding gene TCF21 (transcription factor 21), a tumor suppressor that is transcribed in the sense orientation. In OC samples, the CpG islands associated with the TCF21 and TARID promoter regions are hypermethylated, and both genes are repressed. In contrast, in normal ovarian epithelium, the promoters are unmethylated, and both transcripts are expressed. It was shown that TARID binds to the promoter of its target gene and recruits GADD45A (growth arrest and DNA damage-inducible alpha), a stress response protein [88]. GADD45A expression level is commonly decreased in different cancer types. Interestingly, one functional single nucleotide polymorphism mapped to this gene is related to significantly decreased GADD45A mRNA levels and was implicated in OC susceptibility and prognosis [100]. Recent evidence has suggested that GADD45A recognizes the DNA-IncRNA hybrid formed at the CpG island of the TCF21 promoter, rather than its sequence, and attracts the DNA demethylation machinery to activate the transcription of this gene. Consequently, GADD45A was proposed to be an epigenetic reader [101]. It recruits TDG (thymine DNA glycosylase), a component of the deamination-base excision repair machinery (BER), and proteins of the TET (ten-eleven translocation) family to the TCF21 promoter [88]. TETs are epigenetic erasers known for their role as DNA demethylases in mammals; they oxidize 5-methylcytosine $(5 \mathrm{mC})$ to 5-hydroxymethylcytosine $(5 \mathrm{hmC})$, and afterward to 5-formylcytosine $(5 \mathrm{fC})$ or 5-carboxylcytosine $(5 \mathrm{caC})$. The residues of $5 \mathrm{fC}$ and $5 \mathrm{caC}$ can be replaced by unmodified cytosine following excision by TDG and repair of the abasic site by BER. This process is called active modification-active removal and occurs independently of DNA replication [102].

The examples of epigenetic mechanisms mediated by lncRNAs presented here could help to uncover new regulatory interactions between lncRNAs and epigenetic machinery components. Considering the PRC2 promiscuous binding to RNAs along with the estimate that more than $20 \%$ of 
human lncRNAs are associated with PRCs and chromatin-remodeling complexes, the recruitment of EZH2 and other less-studied mechanisms described herein are likely to apply to some of the still uncharacterized lncRNAs as well $[103,104]$. Furthermore, our portrayal of lncRNAs associated with epigenetic machinery elements provide frameworks that could be explored in future studies to characterize the function of OC-associated lncRNAs.

\section{A Concise Guide to Exploring lncRNA Databases}

The significant amount of data generated using low- and high-throughput methods for the identification and functional characterization of lncRNAs has been organized and updated in many user-friendly databases. Overall, these comprehensive databases provide basic information such as lncRNA annotation, IncRNA-target interactions, the affected biological processes, and lncRNA-mediated regulatory mechanisms in human diseases (transcriptional regulation, epigenetic regulation, chromatin looping, competing endogenous RNA or miRNA sponge, relationships with mRNAs and proteins). They are useful for analyzing and defining the best candidates for further investigations when considering the involvement of lncRNAs in human diseases. The databases summarized herein are publicly available and have information collected on the association between lncRNAs and human diseases. Thus, they are invaluable resources to discover novel biomarkers and potential therapeutic targets for ovarian tumors.

Concurrently, the selected databases are focused on different aspects of IncRNA biology. Therefore, we grouped them into three major categories that can be used as a guide to browse these resources. Based on their main focuses, i.e., annotation of lncRNAs, regulatory functions, or association with human diseases and phenotypes, we summarized this set of representative databases in Table 2. Table S1 includes features of these databases, such as data sources, coverage, and other relevant information. For instance, NONCODE, LNCipedia, LncRNAWiki, EVLncRNAs, LncRBase, and LncBook are mainly dedicated to annotating lncRNAs [105-110]. Although the data sources of these databases partly overlap, some of them also integrate information on IncRNAs from different species, their functions, sequence conservation, and other details. Most importantly, all of them include associations between IncRNAs and human cancers. Among these resources, LncBook is the most comprehensive in terms of the number of human IncRNAs, which amounts to 268,848 transcripts and 140,356 genes. Considering the disease-related lncRNAs gathered by this knowledgebase, HOTAIR, MALAT1, H19, MEG3 (maternally expressed 3), CDKN2B-AS1, PVT1, NEAT1, and GAS5 are some of the most studied. Each of these IncRNAs has been associated with at least 30 diseases, including OC [108].

Table 2. Summary of lncRNA databases (last accessed on July, 2020).

\begin{tabular}{|c|c|c|c|}
\hline Database & Aim & Website & Refs. \\
\hline \multicolumn{4}{|l|}{ lncRNA annotation } \\
\hline NONCODE v5.0 & $\begin{array}{l}\text { Collects and annotates } \\
\text { a comprehensive set of } \\
\text { ncRNAs, especially } \\
\text { lncRNAs. }\end{array}$ & $\begin{array}{c}\text { http: } \\
\text { //www.noncode.org/ }\end{array}$ & [105] \\
\hline LNCipedia 5.2 & $\begin{array}{l}\text { Collects sequences and } \\
\text { annotation data for } \\
\text { a comprehensive set of } \\
\text { lncRNA transcripts. }\end{array}$ & https://lncipedia.org & {$[107,111]$} \\
\hline LncRNAWiki & $\begin{array}{l}\text { Collects and integrates } \\
\text { comprehensive } \\
\text { information on human } \\
\text { lncRNAs relying on } \\
\text { collaborative curation. }\end{array}$ & http://lncrna.big.ac.cn & {$[110,112]$} \\
\hline
\end{tabular}


Table 2. Cont.

\begin{tabular}{|c|c|c|c|}
\hline Database & Aim & Website & Refs. \\
\hline EVLncRNAs & $\begin{array}{l}\text { Collects lncRNAs that } \\
\text { were validated by } \\
\text { low-throughput } \\
\text { experiments. }\end{array}$ & $\begin{array}{l}\text { http://biophy.dzu.edu. } \\
\text { cn/EVLncRNAs }\end{array}$ & [109] \\
\hline LncRBase & $\begin{array}{l}\text { Provides information on } \\
\text { a comprehensive set of } \\
\text { lncRNAs, ranging from } \\
\text { basic transcript features } \\
\text { to additional details on } \\
\text { their genomic context. }\end{array}$ & $\begin{array}{c}\text { http: } \\
\text { //bicresources.jcbose.ac. } \\
\text { in/zhumur/lncrbase }\end{array}$ & [106] \\
\hline LncBook & $\begin{array}{l}\text { Collects a comprehensive } \\
\text { set of human lncRNAs } \\
\text { and provides } \\
\text { multi-omics data } \\
\text { integration, functional } \\
\text { annotation, and disease } \\
\text { association for these } \\
\text { transcripts. }\end{array}$ & $\begin{array}{c}\text { http: } \\
\text { //bigd.big.ac.cn/lncbook }\end{array}$ & {$[108,113]$} \\
\hline \multicolumn{4}{|c|}{ lncRNA regulatory functions (interactions, mechanisms, and effects) } \\
\hline ENCORI & $\begin{array}{l}\text { Integrates } \\
\text { multi-dimensional } \\
\text { sequencing data to } \\
\text { provide a comprehensive } \\
\text { collection of RNA-RNA } \\
\text { and protein-RNA } \\
\text { interaction networks. }\end{array}$ & $\begin{array}{c}\text { http: } \\
\text { //starbase.sysu.edu.cn/ }\end{array}$ & {$[114,115]$} \\
\hline LncRNA2Target v2.0 & $\begin{array}{l}\text { Collects lncRNA-target } \\
\text { associations supported } \\
\text { by high- and } \\
\text { low-throughput } \\
\text { methods. }\end{array}$ & $\begin{array}{l}\text { http://123.59.132.21/ } \\
\text { lncrna2target/ }\end{array}$ & [116] \\
\hline LncTarD & $\begin{array}{l}\text { Collects and illustrates } \\
\text { experimentally } \\
\text { supported } \\
\text { lncRNA-target } \\
\text { regulations in human } \\
\text { diseases. }\end{array}$ & $\begin{array}{c}\text { http://bio-bigdata. } \\
\text { hrbmu.edu.cn/LncTarD }\end{array}$ & [117] \\
\hline NPInter v4.0 & $\begin{array}{l}\text { Integrates literature } \\
\text { reported evidence and } \\
\text { high-throughput data } \\
\text { processing to collect and } \\
\text { illustrate functional } \\
\text { interactions between } \\
\text { ncRNAs and } \\
\text { biomolecules. }\end{array}$ & $\begin{array}{l}\text { http://bigdata.ibp.ac.cn/ } \\
\text { npinter }\end{array}$ & [118] \\
\hline LncACTdb 2.0 & $\begin{array}{l}\text { Collects and illustrates } \\
\text { information on ceRNA } \\
\text { relationships between } \\
\text { different types of RNAs } \\
\text { in diverse diseases. }\end{array}$ & $\begin{array}{l}\text { http://www.bio-bigdata. } \\
\text { net/LncACTdb/ }\end{array}$ & [119] \\
\hline miRSponge & $\begin{array}{l}\text { Collects experimentally } \\
\text { validated miRNA } \\
\text { sponges and ceRNA } \\
\text { interactions. }\end{array}$ & $\begin{array}{c}\text { http: } \\
\text { //bio-bigdata.hrbmu.edu. } \\
\text { cn/miRSponge/ }\end{array}$ & [120] \\
\hline
\end{tabular}


Table 2. Cont.

\begin{tabular}{|c|c|c|c|}
\hline Database & Aim & Website & Refs. \\
\hline Co-LncRNA & $\begin{array}{l}\text { Allows the identification } \\
\text { of lncRNA coexpressed } \\
\text { protein-coding genes } \\
\text { and the assessment of } \\
\text { the effects of individual } \\
\text { or multiple lncRNAs in } \\
\text { GO annotations and } \\
\text { KEGG pathways. }\end{array}$ & $\begin{array}{c}\text { http: } \\
\text { //bio-bigdata.hrbmu.edu. } \\
\text { cn/Co-LncRNA/ }\end{array}$ & [121] \\
\hline Lnc2Meth & $\begin{array}{l}\text { Integrates experimental } \\
\text { and computational } \\
\text { evidence to provide } \\
\text { information on } \\
\text { regulatory relationships } \\
\text { between lncRNAs and } \\
\text { DNA methylation in } \\
\text { diverse human diseases. }\end{array}$ & $\begin{array}{c}\text { http: } \\
\text { //bio-bigdata.hrbmu.edu. } \\
\text { cn/Lnc2Meth/ }\end{array}$ & [122] \\
\hline \multicolumn{4}{|c|}{ lncRNA-disease associations } \\
\hline LncRNADisease 2.0 & $\begin{array}{l}\text { Integrates experimental } \\
\text { and computational } \\
\text { evidence } \\
\text { to provide information on } \\
\text { lncRNA/circRNA-disease } \\
\text { associations, including } \\
\text { causal relationships. }\end{array}$ & $\begin{array}{l}\text { http://www.rnanut.net/ } \\
\text { lncrnadisease/ }\end{array}$ & {$[123,124]$} \\
\hline Lnc2Cancer v3.0 & $\begin{array}{l}\text { Collects and integrates } \\
\text { experimentally } \\
\text { supported associations } \\
\text { between lncRNAs and } \\
\text { cancer subtypes. }\end{array}$ & $\begin{array}{l}\text { http://www.bio-bigdata. } \\
\text { net/lnc2cancer/ }\end{array}$ & {$[125,126]$} \\
\hline MNDR v2.0 & $\begin{array}{l}\text { Collects and integrates } \\
\text { experimentally } \\
\text { supported and predicted } \\
\text { ncRNA-disease } \\
\text { associations in } \\
\text { mammals. }\end{array}$ & $\begin{array}{c}\text { http://www.rna-society. } \\
\text { org/mndr/ }\end{array}$ & [127] \\
\hline ncRPheno & $\begin{array}{l}\text { Collects comprehensive } \\
\text { ncRNA-disease } \\
\text { association data and } \\
\text { offers web applications } \\
\text { to facilitate analysis and } \\
\text { visualization of this data. }\end{array}$ & $\begin{array}{l}\text { http://lilab2.sysu.edu.cn/ } \\
\text { ncrpheno }\end{array}$ & [128] \\
\hline Lnc2Catlas & $\begin{array}{l}\text { Integrates multiple } \\
\text { methods and data } \\
\text { sources to collect } \\
\text { quantitative associations } \\
\text { between lncRNAs and } \\
\text { cancer. }\end{array}$ & $\begin{array}{l}\text { http://lnc2catlas. } \\
\text { bioinfotech.org/ }\end{array}$ & [129] \\
\hline CSCD & $\begin{array}{l}\text { Collects and integrates } \\
\text { information on } \\
\text { cancer-specific circRNAs. }\end{array}$ & $\begin{array}{c}\text { http: } \\
\text { //gb.whu.edu.cn/CSCD }\end{array}$ & [130] \\
\hline Circ2Disease & $\begin{array}{l}\text { Collects information on } \\
\text { experimentally } \\
\text { supported circRNAs in } \\
\text { human diseases. }\end{array}$ & $\begin{array}{l}\text { http://bioinformatics.zju. } \\
\text { edu.cn/Circ2Disease/ } \\
\text { index.html }\end{array}$ & [131] \\
\hline
\end{tabular}


Table 2. Cont.

\begin{tabular}{clcc}
\hline Database & \multicolumn{1}{c}{ Aim } & Website & Refs. \\
\hline CircR2Disease & $\begin{array}{l}\text { Collects information on } \\
\text { experimentally validated } \\
\text { associations between } \\
\text { circRNAs and diseases. }\end{array}$ & $\begin{array}{c}\text { http://bioinfo.snnu.edu. } \\
\text { cn/CircR2Disease/ }\end{array}$ & [132,133] \\
\hline MiOncoCirc & $\begin{array}{l}\text { Collects data on circRNA } \\
\text { formation and } \\
\text { abundance in cancer. }\end{array}$ & $\begin{array}{c}\text { https: } \\
\text { //mioncocirc.github.io/ }\end{array}$ & {$[134]$} \\
\hline
\end{tabular}

The regulatory functions of lncRNAs could be especially explored in databases such as ENCORI, LncRNA2Target, LncTarD, and NPInter, which dive into interactions between these transcripts and different types of biomolecules [114,116-118]. Two other databases, LncACTdb and miRSponge, curate miRNA-sponge relationships $[119,120]$. Endogenous transcripts that share the same miRNA-binding sites can compete for the corresponding miRNA and regulate each other post-transcriptionally by titrating miRNA availability [135]. These transcripts, called competing endogenous RNA (ceRNAs), are comprised of noncoding and protein-coding RNAs, and the role of these regulators in cancer can be found in Salmena et al. (2011) and Yang et al. (2016) [136,137]. ENCORI provides a comprehensive collection of RNA-RNA and protein-RNA interaction networks. Lnc2Target collects lncRNA-target associations validated by high- and low-throughput methods. Emphasizing the contribution of lncRNAs to pathogenesis in humans, LncTarD only collects disease-related lncRNA-target regulations. On the other hand, NPInter curates functional interactions between ncRNAs and DNA, proteins, or other types of RNA across numerous organisms. Lately, the concern about offering tools that facilitate the analyses of the information available in databases has been raised, and each of these resources, except for LncRNA2Target and miRSponge, contains applications that illustrate the interactions between IncRNAs and their putative partners. Co-LncRNA and Lnc2Meth are also devoted to the elucidation of regulatory roles of human lncRNAs, the first analyzing downstream effects, and the second focusing on a mechanism [121,122]. Co-LncRNA employs RNA-seq data to assess the effects of individual or multiple lncRNAs in GO annotations and KEGG pathways, whereas Lnc2Meth links lncRNAs to DNA methylation status in several diseases.

Other databases were specially built to provide information on IncRNA-disease associations, such as LncRNADisease, Lnc2Cancer, MNDR, ncRPheno, and Lnc2Catlas [123,125,127-129]. LncRNADisease combines experimental and bioinformatic evidence to provide information on relationships between IncRNAs or circRNAs and diseases. It is the first lncRNA-disease association database that documents causal relationships, mostly cancer-related, which were identified based on strong experimental evidence from in vitro and/or in vivo models [124]. Lnc2Cancer strictly gathers associations supported by experimental evidence and human cancer subtypes, whereas MNDR is dedicated to both experimentally validated and predicted ncRNA-disease associations across six mammalian species. ncRPheno provides several web applications to facilitate the analysis and visualization of ncRNA-disease associations. Lnc2Catlas relies on three scoring methods to collect associations between lncRNAs and cancer. Additionally, some of the resources exemplified by CSCD, Circ2Disease, CircR2Disease, and MiOncoCirc cover the involvement of circRNAs in diseases exclusively [130-132,134]. MiOncoCirc is the first circRNA database to include datasets derived from clinical tumor samples. All MiOncoCirc samples were processed with the poly(A)-independent exome capture RNA-seq protocol, an approach that was proven to be more reliable than the often-used RNase $\mathrm{R}$ and rRNA removal methods. This database supports the identification of tissue-specific transcripts that could be further explored as biomarkers in cancer [134].

Bioinformatic tools also help to unveil the association between lncRNAs and different cancer types. The Atlas of Noncoding RNAs in Cancer (TANRIC) data portal is a platform for interactive analysis of clinical and genomic data coupled to lncRNA expression in cancer, including RNA-seq data 
from TCGA, independent studies, and cell lines from Cancer Cell Line Encyclopedia [138]. OncoLnc is an online resource that integrates survival data from TCGA and RNA-seq expression data for mRNAs, miRNAs, and lncRNAs to enable the exploration of survival correlations, besides allowing the download of the data used in the analyses [139]. Finally, LncDisease is a standalone software that relies on a sequence-based method to predict associations between lncRNAs and human diseases. The analysis involves two steps: (i) the prediction of miRNAs that interact with the inputted lncRNAs and (ii) the disease enrichment analysis of the predicted miRNAs, providing a list of significant diseases potentially associated with lncRNAs [140].

\section{Conclusions and Perspectives}

The altered expression profiles of lncRNAs in cancer, their tissue specificity, and regulatory roles highlight the importance of elucidating IncRNAs functions for new advances in OC diagnosis, prognosis, and therapy. Despite the promising findings, greatly accelerated by high-throughput and in silico approaches, and the large number of IncRNA in the human genome, few cancer-related lncRNAs have been characterized, annotated, and explored to shed light on their potential for clinical applications.

Currently, the development of epi-drugs, comprising compounds targeting enzymes involved in epigenetic regulations, has been limited by the lack of biomarkers for proper patient stratification for clinical trials [141]. Furthermore, interfering with a single epigenetic alteration can lead to global and local effects on chromatin conformation affecting several biological processes and pathways [142]. The regulation of the epigenetic machinery by multiple lncRNAs includes an additional layer of complexity. These transcripts can serve a dual purpose: allowing specific interference with selected targets and a more robust evaluation of patients' responses to the treatment with epi-drugs. The technology for silencing specific lncRNA already exists; however, our knowledge of the widespread functions and interactions of lncRNAs is still limited.

In order to target lncRNAs for further investigations and the development of novel therapeutic strategies, ASOs (antisense nucleotides), siRNAs, and the CRISPR (clustered regularly interspaced short palindromic repeats) system are some of the available methodologies [21]. Each of these approaches offer different routes to achieve the lncRNA modulation and particular advantages and pitfalls that should be appreciated according to the features of the intended targets. ASOs, for instance, are single-stranded deoxyribonucleotide molecules that can hybridize with complementary lncRNAs and attract RNase $\mathrm{H}$ to degrade the target RNA. These oligonucleotides can be modified to improve their intracellular stability and are equally successful in silencing nuclear and cytoplasmic transcripts [143]. In contrast, siRNAs are less effective for the depletion of nuclear lncRNAs and, consequently, are preferable for cytoplasmic applications [144]. The CRISPR system can be used to knockout the target IncRNA genes when coupled with endonuclease Cas9, which produces DSBs in specific DNA sequences, or to repress the target lncRNA transcription when coupled with catalytically dead Cas9 (dCas9) fused to KRAB (Kruppel-associated box) chromatin modifier domain [143,145]. Hopefully, the information and guidelines provided here can help with the design of future studies employing the aforementioned methods to gain more insight into how lncRNAs can be exploited as biomarkers and therapeutic targets in OC.

Supplementary Materials: The following are available online at http:/www.mdpi.com/2072-6694/12/9/2701/s1: Table S1: Publicly available lncRNA databases and their main features (last accessed on July 2020).

Author Contributions: Conceptualization, N.C., C.A.R., and S.R.R.; literature survey and database curation, N.C.; writing - original draft preparation, N.C., C.A., and C.A.R.; writing-review and editing the full content of the manuscript, C.A.R. and S.R.R. All authors have read and agreed to the published version of the manuscript.

Funding: This research was supported by the Region of Southern Denmark Research Fund, DK. Naiade Calanca. and Cláudia Aparecida Rainho received fellowships from the Coordenação de Aperfeiçoamento de Pessoal de Nível Superior-Brasil (CAPES), Finance Code 001, and Unesp-PrInt CAPES project, respectively.

Conflicts of Interest: The authors declare no conflict of interest. The funders had no role in the design of the study; in the collection, analyses, or interpretation of data; in the writing of the manuscript, or in the decision to publish the results. 


\section{References}

1. Timmermans, M.; Sonke, G.S.; Van de Vijver, K.K.; van der Aa, M.A.; Kruitwagen, R.F.P.M. No improvement in long-term survival for epithelial ovarian cancer patients: A population-based study between 1989 and 2014 in the Netherlands. Eur. J. Cancer 2018, 88, 31-37. [CrossRef] [PubMed]

2. Sant, M.; Chirlaque Lopez, M.D.; Agresti, R.; Sánchez Pérez, M.J.; Holleczek, B.; Bielska-Lasota, M.; Dimitrova, N.; Innos, K.; Katalinic, A.; Langseth, H.; et al. Survival of women with cancers of breast and genital organs in Europe 1999-2007: Results of the EUROCARE-5 study. Eur. J. Cancer 2015, 51, 2191-2205. [CrossRef] [PubMed]

3. Global Cancer Observatory GLOBOCAN 2018: Ovary Fact Sheet. Available online: https://gco.iarc.fr/today/ data/factsheets/cancers/25-Ovary-fact-sheet.pdf (accessed on 24 February 2020).

4. Bray, F.; Ferlay, J.; Soerjomataram, I.; Siegel, R.L.; Torre, L.A.; Jemal, A. Global cancer statistics 2018: GLOBOCAN estimates of incidence and mortality worldwide for 36 cancers in 185 countries. CA Cancer J. Clin. 2018, 68, 394-424. [CrossRef] [PubMed]

5. Blagden, S.P. Harnessing Pandemonium: The Clinical Implications of Tumor Heterogeneity in Ovarian Cancer. Front. Oncol. 2015, 5, 149. [CrossRef]

6. McCluggage, W.G. Morphological subtypes of ovarian carcinoma: A review with emphasis on new developments and pathogenesis. Pathology 2011, 43, 420-432. [CrossRef]

7. Lisio, M.A.; Fu, L.; Goyeneche, A.; Gao, Z.H.; Telleria, C. High-grade serous ovarian cancer: Basic sciences, clinical and therapeutic standpoints. Int. J. Mol. Sci. 2019, 20, 952. [CrossRef]

8. Matulonis, U.A.; Sood, A.K.; Fallowfield, L.; Howitt, B.E.; Sehouli, J.; Karlan, B.Y. Ovarian cancer. Nat. Rev. Dis. Prim. 2016, 2, 16061. [CrossRef]

9. Menon, U.; Karpinskyj, C.; Gentry-Maharaj, A. Ovarian Cancer Prevention and Screening. Obstet. Gynecol. 2018, 131, 909-927. [CrossRef]

10. Goff, B.A.; Mandel, L.; Muntz, H.G.; Melancon, C.H. Ovarian carcinoma diagnosis. Cancer 2000, 89, $2068-2075$. [CrossRef]

11. Tan, D.S.; Agarwal, R.; Kaye, S.B. Mechanisms of transcoelomic metastasis in ovarian cancer. Lancet Oncol. 2006, 7, 925-934. [CrossRef]

12. Cancer Research UK Ovarian Cancer Survival Statistics. Available online: https://www.cancerresearchuk. org/health-professional/cancer-statistics/statistics-by-cancer-type/ovarian-cancer/survival (accessed on 24 February 2020).

13. Moore, K.; Colombo, N.; Scambia, G.; Kim, B.-G.; Oaknin, A.; Friedlander, M.; Lisyanskaya, A.; Floquet, A.; Leary, A.; Sonke, G.S.; et al. Maintenance Olaparib in Patients with Newly Diagnosed Advanced Ovarian Cancer. N. Engl. J. Med. 2018, 379, 2495-2505. [CrossRef] [PubMed]

14. Boyd, L.R.; Muggia, F.M. Carboplatin/Paclitaxel Induction in Ovarian Cancer: The Finer Points. Oncology 2018, 32, 418-420, 422-424. [PubMed]

15. Piovesan, A.; Antonaros, F.; Vitale, L.; Strippoli, P.; Pelleri, M.C.; Caracausi, M. Human protein-coding genes and gene feature statistics in 2019. BMC Res. Notes 2019, 12, 315. [CrossRef] [PubMed]

16. Dunham, I.; Kundaje, A.; Aldred, S.F.; Collins, P.J.; Davis, C.A.; Doyle, F.; Epstein, C.B.; Frietze, S.; Harrow, J.; Kaul, R.; et al. An integrated encyclopedia of DNA elements in the human genome. Nature 2012, 489, 57-74. [CrossRef]

17. Rasool, M.; Malik, A.; Zahid, S.; Basit Ashraf, M.A.; Qazi, M.H.; Asif, M.; Zaheer, A.; Arshad, M.; Raza, A.; Jamal, M.S. Non-coding RNAs in cancer diagnosis and therapy. NonCoding RNA Res. 2016, 1, 69-76. [CrossRef]

18. Derrien, T.; Johnson, R.; Bussotti, G.; Tanzer, A.; Djebali, S.; Tilgner, H.; Guernec, G.; Martin, D.; Merkel, A.; Knowles, D.G.; et al. The GENCODE v7 catalog of human long noncoding RNAs: Analysis of their gene structure, evolution, and expression. Genome Res. 2012, 22, 1775-1789. [CrossRef]

19. Rasmussen, T.P. Parallels between artificial reprogramming and the biogenesis of cancer stem cells: Involvement of lncRNAs. Semin. Cancer Biol. 2019, 57, 36-44. [CrossRef]

20. Fu, D.; Shi, Y.; Liu, J.-B.; Wu, T.-M.; Jia, C.-Y.; Yang, H.-Q.; Zhang, D.-D.; Yang, X.-L.; Wang, H.-M.; Ma, Y.-S. Targeting Long Non-coding RNA to Therapeutically Regulate Gene Expression in Cancer. Mol. Ther. Nucleic Acids 2020, 21, 712-724. [CrossRef] 
21. De Oliveira, J.C.; Oliveira, L.C.; Mathias, C.; Pedroso, G.A.; Lemos, D.S.; Salviano-Silva, A.; Jucoski, T.S.; Lobo-Alves, S.C.; Zambalde, E.P.; Cipolla, G.A.; et al. Long non-coding RNAs in cancer: Another layer of complexity. J. Gene Med. 2019, 21, 1-18. [CrossRef]

22. Hanahan, D.; Weinberg, R.A. Hallmarks of cancer: The next generation. Cell 2011, 144, 646-674. [CrossRef]

23. Zhang, X.-Z.; Liu, H.; Chen, S.-R. Mechanisms of Long Non-Coding RNAs in Cancers and Their Dynamic Regulations. Cancers 2020, 12, 1245. [CrossRef] [PubMed]

24. Hanly, D.J.; Esteller, M.; Berdasco, M. Interplay between long non-coding RNAs and epigenetic machinery: Emerging targets in cancer? Philos. Trans. R. Soc. B Biol. Sci. 2018, 373, 20170074. [CrossRef] [PubMed]

25. Kong, L.; Zhang, C. LncRNA DLX6-AS1 aggravates the development of ovarian cancer via modulating FHL2 by sponging miR-195-5p. Cancer Cell Int. 2020, 20,1-12. [CrossRef] [PubMed]

26. Zhao, H.; Ding, F.; Zheng, G. LncRNA TMPO-AS1 promotes LCN2 transcriptional activity and exerts oncogenic functions in ovarian cancer. FASEB J. 2020, 34, 11382-11394. [CrossRef]

27. Elsayed, A.M.; Amero, P.; Salama, S.A.; Abdelaziz, A.H.; Lopez-Berestein, G.; Rodriguez-Aguayo, C. Back to the Future: Rethinking the Great Potential of lncRNAS for Optimizing Chemotherapeutic Response in Ovarian Cancer. Cancers 2020, 12, 2406. [CrossRef]

28. Silva, A.; Bullock, M.; Calin, G. The clinical relevance of long non-coding RNAs in cancer. Cancers 2015, 7, 2169-2182. [CrossRef]

29. Bhan, A.; Mandal, S.S. LncRNA HOTAIR: A master regulator of chromatin dynamics and cancer. Biochim. Biophys. Acta Rev. Cancer 2015, 1856, 151-164. [CrossRef]

30. Wang, H.; Fu, Z.; Dai, C.; Cao, J.; Liu, X.; Xu, J.; Lv, M.; Gu, Y.; Zhang, J.; Hua, X.; et al. LncRNAs expression profiling in normal ovary, benign ovarian cyst and malignant epithelial ovarian cancer. Sci. Rep. 2016, 6, 38983. [CrossRef]

31. Abildgaard, C.; Do Canto, L.M.; Steffensen, K.D.; Rogatto, S.R. Long Non-coding RNAs Involved in Resistance to Chemotherapy in Ovarian Cancer. Front. Oncol. 2020, 9, 1-17. [CrossRef]

32. Xu, L.; Wu, Y.; Che, X.; Zhao, J.; Wang, F.; Wang, P.; Qu, X.; Liu, Y.P.; Li, Z. Cox-LASSO Analysis Reveals a Ten-lncRNA Signature to Predict Outcomes in Patients with High-Grade Serous Ovarian Cancer. DNA Cell Biol. 2019, 38, 1519-1528. [CrossRef]

33. Teschendorff, A.E.; Lee, S.H.; Jones, A.; Fiegl, H.; Kalwa, M.; Wagner, W.; Chindera, K.; Evans, I.; Dubeau, L.; Orjalo, A.; et al. HOTAIR and its surrogate DNA methylation signature indicate carboplatin resistance in ovarian cancer. Genome Med. 2015, 7, 1-12. [CrossRef] [PubMed]

34. Wang, J.; Lu, A.; Chen, L. LncRNAs in ovarian cancer. Clin. Chim. Acta 2019, 490, 17-27. [CrossRef] [PubMed]

35. Zhan, L.; Li, J.; Wei, B. Long non-coding RNAs in ovarian cancer. J. Exp. Clin. Cancer Res. 2018, $37,120$. [CrossRef] [PubMed]

36. Nam, J.W.; Choi, S.W.; You, B.H. Incredible RNA: Dual Functions of Coding and Noncoding. Mol. Cells 2016, 39, 367-374. [CrossRef] [PubMed]

37. Wu, P.; Mo, Y.; Peng, M.; Tang, T.; Zhong, Y.; Deng, X.; Xiong, F.; Guo, C.; Wu, X.; Li, Y.; et al. Emerging role of tumor-related functional peptides encoded by lncRNA and circRNA. Mol. Cancer 2020, 19, 22. [CrossRef] [PubMed]

38. Li, J.; Liu, C. Coding or Noncoding, the Converging Concepts of RNAs. Front. Genet. 2019, 10, 1-10. [CrossRef]

39. Iyer, M.K.; Niknafs, Y.S.; Malik, R.; Singhal, U.; Sahu, A.; Hosono, Y.; Barrette, T.R.; Prensner, J.R.; Evans, J.R.; Zhao, S.; et al. The landscape of long noncoding RNAs in the human transcriptome. Nat. Genet. 2015, 47, 199-208. [CrossRef]

40. Djebali, S.; Davis, C.A.; Merkel, A.; Dobin, A.; Lassmann, T.; Mortazavi, A.; Tanzer, A.; Lagarde, J.; Lin, W.; Schlesinger, F.; et al. Landscape of transcription in human cells. Nature 2012, 489, 101-108. [CrossRef]

41. Dhanoa, J.K.; Sethi, R.S.; Verma, R.; Arora, J.S.; Mukhopadhyay, C.S. Long non-coding RNA: Its evolutionary relics and biological implications in mammals: A review. J. Anim. Sci. Technol. 2018, 60, 1-10. [CrossRef]

42. Quinn, J.J.; Chang, H.Y. Unique features of long non-coding RNA biogenesis and function. Nat. Rev. Genet. 2016, 17, 47-62. [CrossRef]

43. Ulitsky, I. Evolution to the rescue: Using comparative genomics to understand long non-coding RNAs. Nat. Rev. Genet. 2016, 17, 601-614. [CrossRef] [PubMed]

44. Wang, K.C.; Chang, H.Y. Molecular Mechanisms of Long Noncoding RNAs. Mol. Cell 2011, 43, 904-914. [CrossRef] [PubMed] 
45. Cabili, M.N.; Dunagin, M.C.; McClanahan, P.D.; Biaesch, A.; Padovan-Merhar, O.; Regev, A.; Rinn, J.L.; Raj, A. Localization and abundance analysis of human lncRNAs at single-cell and single-molecule resolution. Genome Biol. 2015, 16, 20. [CrossRef] [PubMed]

46. Morlando, M.; Fatica, A. Alteration of epigenetic regulation by long noncoding RNAs in cancer. Int. J. Mol. Sci. 2018, 19, 570. [CrossRef]

47. Huang, M.-S.; Zhu, T.; Li, L.; Xie, P.; Li, X.; Zhou, H.-H.; Liu, Z.-Q. LncRNAs and CircRNAs from the same gene: Masterpieces of RNA splicing. Cancer Lett. 2018, 415, 49-57. [CrossRef]

48. Kong, Y.; Hsieh, C.H.; Alonso, L.C. ANRIL: A lncRNA at the CDKN2A/B locus with roles in cancer and metabolic disease. Front. Endocrinol. 2018, 9, 1-13. [CrossRef]

49. Burd, C.E.; Jeck, W.R.; Liu, Y.; Sanoff, H.K.; Wang, Z.; Sharpless, N.E. Expression of Linear and Novel Circular Forms of an INK4/ARF-Associated Non-Coding RNA Correlates with Atherosclerosis Risk. PLoS Genet. 2010, 6, e1001233. [CrossRef]

50. Xu, Q.; Deng, B.; Li, M.; Chen, Y.; Zhuan, L. CircRNA-UBAP2 promotes the proliferation and inhibits apoptosis of ovarian cancer though miR-382-5p/PRPF8 axis. J. Ovarian Res. 2020, 13, 1-10. [CrossRef]

51. Wang, J.; Wu, A.; Yang, B.; Zhu, X.; Teng, Y.; Ai, Z. Profiling and bioinformatics analyses reveal differential circular RNA expression in ovarian cancer. Gene 2020, 724, 144150. [CrossRef]

52. Zhao, X.; Cai, Y.; Xu, J. Circular RNAs: Biogenesis, Mechanism, and Function in Human Cancers. Int. J. Mol. Sci. 2019, 20, 3926. [CrossRef]

53. Arnaiz, E.; Sole, C.; Manterola, L.; Iparraguirre, L.; Otaegui, D.; Lawrie, C.H. CircRNAs and cancer: Biomarkers and master regulators. Semin. Cancer Biol. 2019, 58, 90-99. [CrossRef] [PubMed]

54. Vitiello, M.; Tuccoli, A.; Poliseno, L. Long non-coding RNAs in cancer: Implications for personalized therapy. Cell. Oncol. 2015, 38, 17-28. [CrossRef] [PubMed]

55. Haddadi, N.; Lin, Y.; Travis, G.; Simpson, A.M.; McGowan, E.M.; Nassif, N.T. PTEN/PTENP1: "Regulating the regulator of RTK-dependent PI3K/Akt signalling", new targets for cancer therapy. Mol. Cancer 2018, 17, 1-14. [CrossRef] [PubMed]

56. Hu, X.; Sood, A.K.; Dang, C.V.; Zhang, L. The role of long noncoding RNAs in cancer: The dark matter matters. Curr. Opin. Genet. Dev. 2018, 48, 8-15. [CrossRef] [PubMed]

57. Han, Y.-N.; Xia, S.-Q.; Zhang, Y.-Y.; Zheng, J.-H.; Li, W. Circular RNAs: A novel type of biomarker and genetic tools in cancer. Oncotarget 2017, 8, 64551-64563. [CrossRef]

58. Tran, A.M.; Chalbatani, G.M.; Berland, L.; Cruz De los Santos, M.; Raj, P.; Jalali, S.A.; Gharagouzloo, E.; Ivan, C.; Dragomir, M.P.; Calin, G.A. A New World of Biomarkers and Therapeutics for Female Reproductive System and Breast Cancers: Circular RNAs. Front. Cell Dev. Biol. 2020, 8, 1-17. [CrossRef]

59. Poliseno, L. Pseudogenes: Newly Discovered Players in Human Cancer. Sci. Signal. 2012, 5, re5. [CrossRef]

60. Fang, L.; Wang, H.; Li, P. Systematic analysis reveals a lncRNA-mRNA co-expression network associated with platinum resistance in high-grade serous ovarian cancer. Investig. New Drugs 2018, 36, 187-194. [CrossRef]

61. Song, J.; Zhang, W.; Wang, S.; Liu, K.; Song, F.; Ran, L. A panel of 7 prognosis-related long non-coding RNAs to improve platinum-based chemoresistance prediction in ovarian cancer. Int. J. Oncol. 2018, 53, 866-876. [CrossRef]

62. Liu, R.; Zeng, Y.; Zhou, C.F.; Wang, Y.; Li, X.; Liu, Z.Q.; Chen, X.P.; Zhang, W.; Zhou, H.H. Long noncoding RNA expression signature to predict platinum-based chemotherapeutic sensitivity of ovarian cancer patients. Sci. Rep. 2017, 7, 1-10. [CrossRef]

63. Wang, L.; Hu, Y.; Xiang, X.; Qu, K.; Teng, Y. Identification of long non-coding RNA signature for paclitaxel-resistant patients with advanced ovarian cancer. Oncotarget 2017, 8, 64191-64202. [CrossRef] [PubMed]

64. Yang, K.; Hou, Y.; Li, A.; Li, Z.; Wang, W.; Xie, H.; Rong, Z.; Lou, G.; Li, K. Identification of a six-lncRNA signature associated with recurrence of ovarian cancer. Sci. Rep. 2017, 7, 1-10. [CrossRef]

65. Luo, P.; Liu, X.F.; Wang, Y.C.; Li, N.D.; Liao, S.J.; Yu, M.X.; Liang, C.Z.; Tu, J.C. Prognostic value of abnormally expressed lncRNAs in ovarian carcinoma: A systematic review and meta-analysis. Oncotarget 2017, 8 , 23927-23936. [CrossRef] [PubMed]

66. Wang, Y.; Wang, H.; Song, T.; Zou, Y.; Jiang, J.; Fang, L.; Li, P. HOTAIR is a potential target for the treatment of cisplatin-resistant ovarian cancer. Mol. Med. Rep. 2015, 12, 2211-2216. [CrossRef] [PubMed] 
67. Fu, L.L.; Li, C.J.; Xu, Y.; Li, L.Y.; Zhou, X.; Li, D.D.; Chen, S.X.; Wang, F.G.; Zhang, X.Y.; Zheng, L.W. Role of IncRNAs as novel biomarkers and therapeutic targets in ovarian cancer. Crit. Rev. Eukaryot. Gene Expr. 2017, 27, 183-195. [CrossRef]

68. Li, J.; Huang, H.; Li, Y.; Li, L.; Hou, W.; You, Z. Decreased expression of long non-coding RNA GAS5 promotes cell proliferation, migration and invasion, and indicates a poor prognosis in ovarian cancer. Oncol. Rep. 2016, 36, 3241-3250. [CrossRef]

69. Guo, R.; Qin, Y. LEMD1-AS1 Suppresses Ovarian Cancer Progression Through Regulating miR-183-5p/TP53 Axis. Oncol. Targets. Ther. 2020, 13, 7387-7398. [CrossRef]

70. Chang, H.; Zhang, X.; Li, B.; Meng, X. MAGI2-AS3 suppresses MYC signaling to inhibit cell proliferation and migration in ovarian cancer through targeting miR-525-5p/MXD1 axis. Cancer Med. 2020, 1-10. [CrossRef]

71. Liu, S.; Lei, H.; Luo, F.; Li, Y.; Xie, L. The effect of lncRNA HOTAIR on chemoresistance of ovarian cancer through regulation of HOXA7. Biol. Chem. 2018, 399, 485-497. [CrossRef]

72. Bai, L.; Wang, A.; Zhang, Y.; Xu, X.; Zhang, X. Knockdown of MALAT1 enhances chemosensitivity of ovarian cancer cells to cisplatin through inhibiting the Notch1 signaling pathway. Exp. Cell Res. 2018, 366, 161-171. [CrossRef]

73. Wang, H.; Liu, M.; Fang, L.; Jiang, J.; Zhang, Z.; Kuang, Y.; Wang, B.; Shang, X.; Han, P.; Li, Y.; et al. The cisplatin-induced lncRNA PANDAR dictates the chemoresistance of ovarian cancer via regulating SFRS2-mediated p53 phosphorylation. Cell Death Dis. 2018, 9. [CrossRef] [PubMed]

74. Zhang, Y.; Ai, H.; Fan, X.; Chen, S.; Wang, Y.; Liu, L. Knockdown of long non-coding RNA HOTAIR reverses cisplatin resistance of ovarian cancer cells through inhibiting miR-138-5p-regulated EZH2 and SIRT1. Biol. Res. 2020, 53, 1-10. [CrossRef] [PubMed]

75. Blagden, S.; Abdel Mouti, M.; Chettle, J. Ancient and modern: Hints of a core post-transcriptional network driving chemotherapy resistance in ovarian cancer. Wiley Interdiscip. Rev. RNA 2018, 9, e1432. [CrossRef] [PubMed]

76. Liu, E.; Liu, Z.; Zhou, Y.; Mi, R.; Wang, D. Overexpression of long non-coding RNA PVT1 in ovarian cancer cells promotes cisplatin resistance by regulating apoptotic pathways. Int. J. Clin. Exp. Med. 2015, 8, 20565-20572. [PubMed]

77. Hosseini, E.S.; Meryet-Figuiere, M.; Sabzalipoor, H.; Kashani, H.H.; Nikzad, H.; Asemi, Z. Dysregulated expression of long noncoding RNAs in gynecologic cancers. Mol. Cancer 2017, 16, 1-13. [CrossRef]

78. Wang, F.; Zhou, J.; Xie, X.; Hu, J.; Chen, L.; Hu, Q.; Guo, H.; Yu, C. Involvement of SRPK1 in cisplatin resistance related to long non-coding RNA UCA1 in human ovarian cancer cells. Neoplasma 2015, 62, 432-438. [CrossRef]

79. Adriaens, C.; Standaert, L.; Barra, J.; Latil, M.; Verfaillie, A.; Kalev, P.; Boeckx, B.; Wijnhoven, P.W.G.; Radaelli, E.; Vermi, W.; et al. P53 induces formation of NEAT1 lncRNA-containing paraspeckles that modulate replication stress response and chemosensitivity. Nat. Med. 2016, 22, 861-868. [CrossRef]

80. Cheng, Y.; He, C.; Wang, M.; Ma, X.; Mo, F.; Yang, S.; Han, J.; Wei, X. Targeting epigenetic regulators for cancer therapy: Mechanisms and advances in clinical trials. Signal. Transduct. Target. Ther. 2019, 4, 1-39. [CrossRef]

81. Biswas, S.; Rao, C.M. Epigenetic tools (The Writers, The Readers and The Erasers) and their implications in cancer therapy. Eur. J. Pharmacol. 2018, 837, 8-24. [CrossRef]

82. Beckedorff, F.C.; Amaral, M.S.; Deocesano-Pereira, C.; Verjovski-Almeida, S. Long non-coding RNAs and their implications in cancer epigenetics. Biosci. Rep. 2013, 33, 667-675. [CrossRef]

83. Fang, Y.; Fullwood, M.J. Roles, Functions, and Mechanisms of Long Non-coding RNAs in Cancer. Genom. Proteom. Bioinform. 2016, 14, 42-54. [CrossRef] [PubMed]

84. Hu, X.; Feng, Y.; Zhang, D.; Zhao, S.D.; Hu, Z.; Greshock, J.; Zhang, Y.; Yang, L.; Zhong, X.; Wang, L.P.; et al. A Functional Genomic Approach Identifies FAL1 as an Oncogenic Long Noncoding RNA that Associates with BMI1 and Represses p21 Expression in Cancer. Cancer Cell 2014, 26, 344-357. [CrossRef] [PubMed]

85. Activity, E.O. The focally amplified lncRNA FAL1 exhibits oncogenic activity. Cancer Discov. 2014, 4, 1253. [CrossRef]

86. Chen, Y.; Du, H.; Bao, L.; Liu, W. LncRNA PVT1 promotes ovarian cancer progression by silencing miR-214. Cancer Biol. Med. 2018, 15, 238-250. [CrossRef]

87. Delás, M.J.; Hannon, G.J. IncRNAs in development and disease: From functions to mechanisms. Open Biol. 2017, 7, 1-10. [CrossRef] 
88. Arab, K.; Park, Y.J.; Lindroth, A.M.; Schäfer, A.; Oakes, C.; Weichenhan, D.; Lukanova, A.; Lundin, E.; Risch, A.; Meister, M.; et al. Long noncoding RNA TARID directs demethylation and activation of the tumor suppressor TCF21 via GADD45A. Mol. Cell 2014, 55, 604-614. [CrossRef]

89. Zhang, C.; Liu, J.; Zhang, Y.; Luo, C.; Zhu, T.; Zhang, R.; Yao, R. LINC01210 accelerates proliferation, invasion and migration in ovarian cancer through epigenetically downregulating KLF4. Biomed. Pharmacother. 2019, 119, 109431. [CrossRef]

90. Li, Y.; Jiao, Y.; Hao, J.; Xing, H.; Li, C. Long noncoding RNA TP73-AS1 accelerates the epithelial ovarian cancer via epigenetically repressing p21. Am. J. Transl. Res. 2019, 11, 2447-2454.

91. Wang, H.; Su, H.; Tan, Y. UNC5B-AS1 promoted ovarian cancer progression by regulating the H3K27me on NDRG2 via EZH2. Cell Biol. Int. 2020, 44, 1028-1036. [CrossRef]

92. Zeng, X.Y.; Jiang, X.Y.; Yong, J.H.; Xie, H.; Yuan, J.; Zeng, D.; Dou, Y.Y.; Xiao, S.S. lncRNA ABHD11-AS1, regulated by the EGFR pathway, contributes to the ovarian cancer tumorigenesis by epigenetically suppressing TIMP2. Cancer Med. 2019, 8, 7074-7085. [CrossRef]

93. Schuettengruber, B.; Bourbon, H.M.; Di Croce, L.; Cavalli, G. Genome Regulation by Polycomb and Trithorax: 70 Years and Counting. Cell 2017, 171,34-57. [CrossRef] [PubMed]

94. Zhu, S.; Zhao, D.; Yan, L.; Jiang, W.; Kim, J.S.; Gu, B.; Liu, Q.; Wang, R.; Xia, B.; Zhao, J.C.; et al. BMI1 regulates androgen receptor in prostate cancer independently of the polycomb repressive complex 1. Nat. Commun. 2018, 9, 1-13. [CrossRef] [PubMed]

95. Comet, I.; Riising, E.M.; Leblanc, B.; Helin, K. Maintaining cell identity: PRC2-mediated regulation of transcription and cancer. Nat. Rev. Cancer 2016, 16, 803-810. [CrossRef] [PubMed]

96. Jones, B.A.; Varambally, S.; Arend, R.C. Histone Methyltransferase EZH2: A Therapeutic Target for Ovarian Cancer. Mol. Cancer Ther. 2018, 17, 591-602. [CrossRef] [PubMed]

97. Penna, E.; Orso, F.; Taverna, D. miR-214 as a Key Hub that Controls Cancer Networks: Small Player, Multiple Functions. J. Investig. Dermatol. 2015, 135, 960-969. [CrossRef]

98. Wang, B.; Shen, A.; Ouyang, X.; Zhao, G.; Du, Z.; Huo, W.; Zhang, T.; Wang, Y.; Yang, C.; Dong, P.; et al. KLF4 expression enhances the efficacy of chemotherapy drugs in ovarian cancer cells. Biochem. Biophys. Res. Commun. 2017, 484, 486-492. [CrossRef]

99. Yi, X.; Guo, J.; Guo, J.; Sun, S.; Yang, P.; Wang, J.; Li, Y.; Xie, L.; Cai, J.; Wang, Z. EZH2-mediated epigenetic silencing of TIMP2 promotes ovarian cancer migration and invasion. Sci. Rep. 2017, 7, 1-16. [CrossRef]

100. Yuan, C.; Liu, X.; Liu, X.; Yang, N.; Liu, Z.; Yan, S.; Shen, K.; Kong, B. The GADD45A (1506T>C) Polymorphism Is Associated with Ovarian Cancer Susceptibility and Prognosis. PLoS ONE 2015, 10, e0138692. [CrossRef]

101. Arab, K.; Karaulanov, E.; Musheev, M.; Trnka, P.; Schäfer, A.; Grummt, I.; Niehrs, C. GADD45A binds R-loops and recruits TET1 to CpG island promoters. Nat. Genet. 2019, 51, 217-223. [CrossRef]

102. Wu, X.; Zhang, Y. TET-mediated active DNA demethylation: Mechanism, function and beyond. Nat. Rev. Genet. 2017, 18, 517-534. [CrossRef]

103. Nie, L.; Wu, H.J.; Hsu, J.M.; Chang, S.S.; LaBaff, A.M.; Li, C.W.; Wang, Y.; Hsu, J.L.; Hung, M.C. Long non-coding RNAs: Versatile master regulators of gene expression and crucial players in cancer. Am. J. Transl. Res. 2012, 4, 127-150. [PubMed]

104. Davidovich, C.; Zheng, L.; Goodrich, K.J.; Cech, T.R. Promiscuous RNA binding by Polycomb repressive complex 2. Nat. Struct. Mol. Biol. 2013, 20, 1250-1257. [CrossRef] [PubMed]

105. Fang, S.; Zhang, L.; Guo, J.; Niu, Y.; Wu, Y.; Li, H.; Zhao, L.; Li, X.; Teng, X.; Sun, X.; et al. NONCODEV5: A comprehensive annotation database for long non-coding RNAs. Nucleic Acids Res. 2018, 46, D308-D314. [CrossRef] [PubMed]

106. Chakraborty, S.; Deb, A.; Maji, R.K.; Saha, S.; Ghosh, Z. LncRBase: An Enriched Resource for lncRNA Information. PLoS ONE 2014, 9, e108010. [CrossRef] [PubMed]

107. Volders, P.-J.; Anckaert, J.; Verheggen, K.; Nuytens, J.; Martens, L.; Mestdagh, P.; Vandesompele, J. LNCipedia 5: Towards a reference set of human long non-coding RNAs. Nucleic Acids Res. 2019, 47, D135-D139. [CrossRef]

108. Ma, L.; Cao, J.; Liu, L.; Du, Q.; Li, Z.; Zou, D.; Bajic, V.B.; Zhang, Z. LncBook: A curated knowledgebase of human long non-coding RNAs. Nucleic Acids Res. 2019, 47, D128-D134. [CrossRef]

109. Zhou, B.; Zhao, H.; Yu, J.; Guo, C.; Dou, X.; Song, F.; Hu, G.; Cao, Z.; Qu, Y.; Yang, Y.; et al. EVLncRNAs: A manually curated database for long non-coding RNAs validated by low-throughput experiments. Nucleic Acids Res. 2018, 46, D100-D105. [CrossRef] 
110. Ma, L.; Li, A.; Zou, D.; Xu, X.; Xia, L.; Yu, J.; Bajic, V.B.; Zhang, Z. LncRNAWiki: Harnessing community knowledge in collaborative curation of human long non-coding RNAs. Nucleic Acids Res. 2015, 43, D187-D192. [CrossRef]

111. LNCipedia. Available online: https://ncipedia.org (accessed on 27 April 2020).

112. LncRNAWiki. Available online: http://ncrna.big.ac.cn (accessed on 30 April 2020).

113. LncBook. Available online: http://bigd.big.ac.cn/lncbook (accessed on 20 May 2020).

114. Li, J.H.; Liu, S.; Zhou, H.; Qu, L.H.; Yang, J.H. StarBase v2.0: Decoding miRNA-ceRNA, miRNA-ncRNA and protein-RNA interaction networks from large-scale CLIP-Seq data. Nucleic Acids Res. 2014, 42, 92-97. [CrossRef]

115. ENCORI. Available online: http://starbase.sysu.edu.cn/ (accessed on 27 June 2020).

116. Cheng, L.; Wang, P.; Tian, R.; Wang, S.; Guo, Q.; Luo, M.; Zhou, W.; Liu, G.; Jiang, H.; Jiang, Q. LncRNA2Target v2.0: A comprehensive database for target genes of lncRNAs in human and mouse. Nucleic Acids Res. 2019, 47, D140-D144. [CrossRef]

117. Zhao, H.; Shi, J.; Zhang, Y.; Xie, A.; Yu, L.; Zhang, C.; Lei, J.; Xu, H.; Leng, Z.; Li, T.; et al. LncTarD: A manually-curated database of experimentally-supported functional lncRNA-target regulations in human diseases. Nucleic Acids Res. 2020, 48, D118-D126. [CrossRef] [PubMed]

118. Teng, X.; Chen, X.; Xue, H.; Tang, Y.; Zhang, P.; Kang, Q.; Hao, Y.; Chen, R.; Zhao, Y.; He, S. NPInter v4.0: An integrated database of ncRNA interactions. Nucleic Acids Res. 2019, 48, D160-D165. [CrossRef] [PubMed]

119. Wang, P.; Li, X.; Gao, Y.; Guo, Q.; Wang, Y.; Fang, Y.; Ma, X.; Zhi, H.; Zhou, D.; Shen, W.; et al. LncACTdb 2.0: An updated database of experimentally supported ceRNA interactions curated from low-and high-throughput experiments. Nucleic Acids Res. 2019, 47, D121-D127. [CrossRef] [PubMed]

120. Wang, P.; Zhi, H.; Zhang, Y.; Liu, Y.; Zhang, J.; Gao, Y.; Guo, M.; Ning, S.; Li, X. miRSponge: A manually curated database for experimentally supported miRNA sponges and ceRNAs. Database 2015, 2015, bav098. [CrossRef] [PubMed]

121. Zhao, Z.; Bai, J.; Wu, A.; Wang, Y.; Zhang, J.; Wang, Z.; Li, Y.; Xu, J.; Li, X. Co-LncRNA: Investigating the lncRNA combinatorial effects in GO annotations and KEGG pathways based on human RNA-Seq data. Database 2015, 2015, bav082. [CrossRef]

122. Zhi, H.; Li, X.; Wang, P.; Gao, Y.; Gao, B.; Zhou, D.; Zhang, Y.; Guo, M.; Yue, M.; Shen, W.; et al. Lnc2Meth: A manually curated database of regulatory relationships between long non-coding RNAs and DNA methylation associated with human disease. Nucleic Acids Res. 2018, 46, D133-D138. [CrossRef]

123. Bao, Z.; Yang, Z.; Huang, Z.; Zhou, Y.; Cui, Q.; Dong, D. LncRNADisease 2.0: An updated database of long non-coding RNA-associated diseases. Nucleic Acids Res. 2019, 47, D1034-D1037. [CrossRef]

124. Jia, K.; Gao, Y.; Shi, J.; Zhou, Y.; Zhou, Y.; Cui, Q. Annotation and curation of the causality information in LncRNADisease. Database 2020, 2020, baz150. [CrossRef]

125. Gao, Y.; Wang, P.; Wang, Y.; Ma, X.; Zhi, H.; Zhou, D.; Li, X.; Fang, Y.; Shen, W.; Xu, Y.; et al. Lnc2Cancer v2.0: Updated database of experimentally supported long non-coding RNAs in human cancers. Nucleic Acids Res. 2019, 47, D1028-D1033. [CrossRef]

126. Lnc2Cancer 3.0. Available online: http://www.bio-bigdata.net/lnc2cancer/ (accessed on 5 July 2020).

127. Cui, T.; Zhang, L.; Huang, Y.; Yi, Y.; Tan, P.; Zhao, Y.; Hu, Y.; Xu, L.; Li, E.; Wang, D. MNDR v2.0: An updated resource of ncRNA-disease associations in mammals. Nucleic Acids Res. 2018, 46, D371-D374. [CrossRef]

128. Zhang, W.; Yao, G.; Wang, J.; Yang, M.; Wang, J.; Zhang, H.; Li, W. ncRPheno: A comprehensive database platform for identification and validation of disease related noncoding RNAs. RNA Biol. 2020, 17, 943-955. [CrossRef] [PubMed]

129. Ren, C.; An, G.; Zhao, C.; Ouyang, Z.; Bo, X.; Shu, W. Lnc2Catlas: An atlas of long noncoding RNAs associated with risk of cancers. Sci. Rep. 2018, 8, 1-8. [CrossRef] [PubMed]

130. Xia, S.; Feng, J.; Chen, K.; Ma, Y.; Gong, J.; Cai, F.; Jin, Y.; Gao, Y.; Xia, L.; Chang, H.; et al. CSCD: A database for cancer-specific circular RNAs. Nucleic Acids Res. 2018, 46, D925-D929. [CrossRef] [PubMed]

131. Yao, D.; Zhang, L.; Zheng, M.; Sun, X.; Lu, Y.; Liu, P. Circ2Disease: A manually curated database of experimentally validated circRNAs in human disease. Sci. Rep. 2018, 8, 1-6. [CrossRef] [PubMed]

132. Fan, C.; Lei, X.; Fang, Z.; Jiang, Q.; Wu, F.-X. CircR2Disease: A manually curated database for experimentally supported circular RNAs associated with various diseases. Database 2018, 2018, bay044. [CrossRef] [PubMed]

133. CircR2Disease. Available online: http://bioinfo.snnu.edu.cn/CircR2Disease/ (accessed on 26 June 2020). 
134. Vo, J.N.; Cieslik, M.; Zhang, Y.; Shukla, S.; Xiao, L.; Zhang, Y.; Wu, Y.M.; Dhanasekaran, S.M.; Engelke, C.G.; Cao, X.; et al. The Landscape of Circular RNA in Cancer. Cell 2019, 176, 869-881.e13. [CrossRef]

135. Tay, Y.; Rinn, J.; Pandolfi, P.P. The multilayered complexity of ceRNA crosstalk and competition. Nature 2014, 505, 344-352. [CrossRef]

136. Yang, C.; Wu, D.; Gao, L.; Liu, X.; Jin, Y.; Wang, D.; Wang, T.; Li, X. Competing endogenous RNA networks in human cancer: Hypothesis, validation, and perspectives. Oncotarget 2016, 7, 13479-13490. [CrossRef]

137. Salmena, L.; Poliseno, L.; Tay, Y.; Kats, L.; Pandolfi, P.P. A ceRNA hypothesis: The rosetta stone of a hidden RNA language? Cell 2011, 146, 353-358. [CrossRef]

138. Li, J.; Han, L.; Roebuck, P.; Diao, L.; Liu, L.; Yuan, Y.; Weinstein, J.N.; Liang, H. TANRIC: An interactive open platform to explore the function of IncRNAs in cancer. Cancer Res. 2015, 75, 3728-3737. [CrossRef]

139. Anaya, J. OncoLnc: Linking TCGA survival data to mRNAs, miRNAs, and lncRNAs. PeerJ Comput. Sci. 2016, 2, e67. [CrossRef]

140. Wang, J.; Ma, R.; Ma, W.; Chen, J.; Yang, J.; Xi, Y.; Cui, Q. LncDisease: A sequence based bioinformatics tool for predicting lncRNA-disease associations. Nucleic Acids Res. 2016, 44, e90. [CrossRef] [PubMed]

141. Morel, D.; Jeffery, D.; Aspeslagh, S.; Almouzni, G.; Postel-Vinay, S. Combining epigenetic drugs with other therapies for solid tumours-past lessons and future promise. Nat. Rev. Clin. Oncol. 2020, 17, 91-107. [CrossRef] [PubMed]

142. Cossío, F.P.; Esteller, M.; Berdasco, M. Towards a more precise therapy in cancer: Exploring epigenetic complexity. Curr. Opin. Chem. Biol. 2020, 57, 41-49. [CrossRef] [PubMed]

143. Salehi, S.; Taheri, M.N.; Azarpira, N.; Zare, A.; Behzad-Behbahani, A. State of the art technologies to explore long non-coding RNAs in cancer. J. Cell. Mol. Med. 2017, 21, 3120-3140. [CrossRef] [PubMed]

144. Schmitt, A.M.; Chang, H.Y. Long Noncoding RNAs in Cancer Pathways. Cancer Cell 2016, 29, $452-463$. [CrossRef]

145. Gilbert, L.A.; Horlbeck, M.A.; Adamson, B.; Villalta, J.E.; Chen, Y.; Whitehead, E.H.; Guimaraes, C.; Panning, B.; Ploegh, H.L.; Bassik, M.C.; et al. Genome-Scale CRISPR-Mediated Control of Gene Repression and Activation. Cell 2014, 159, 647-661. [CrossRef]

(C) 2020 by the authors. Licensee MDPI, Basel, Switzerland. This article is an open access article distributed under the terms and conditions of the Creative Commons Attribution (CC BY) license (http://creativecommons.org/licenses/by/4.0/). 